\title{
Equilibrium and Thermodynamic Studies of Removal of Two Dyes from Aqueous Solutions using Low Cost Adsorbent
}

\author{
Zainab Hussain \\ Department of Chemistry, College of Science, Misan University, Misan-Iraq.
}

\begin{abstract}
The capability of the low cost materials viz. Dried Mint Leaves (DML) to eliminate two cationic dyes, Methylene Blue (MB) and Safranin-O (SF-O) from an aquatic solutions was studied by the technique of batch mode adsorption process. Influence of contact time, initial dye concentration $(\mathrm{mg} / \mathrm{L})$, adsorbent amount $(\mathrm{g} / \mathrm{L})$ and temperature was investigated. The equilibrium and thermodynamic peculiarities of the dyes abscession were too inspected. The empirical data were found to comply the Langmuir and Freundlich models. Also Dubinin-Radushkevich model show that the process was physisorption. The negative free energy pointed to that the adsorption processes were spontaneously feasible. The process of adsorption has been existed to be exothermic in nature. The abscession of MB was found to be more spontaneous and feasible than the removal of SF-O on the adsorbent. [DOI: 10.22401/JNUS.21.3.03]
\end{abstract}

Keywords: Adsorption, Methylene blue, Safranin-O, Dried Mint Leaves, Adsorption Isotherms.

\section{Introduction}

Water contamination by dyes is a widereaching problematic essentially in textile manufacturing where sizable quantities of dye effluents secede from the dying process [1]. It has been displayed that about $1 \times 10^{4}$ diverse textile dyes with a predictable annually outputting of $7 \times 10^{5}$ metric tons are commercially affordable worldwide [2]. A multitude of dyes are complex organic molecules and are opposed to climate, the action of detergents, etc.[3]. Dyes are opposition to fading on contact to light, water, and many chemicals and hence, are hard to be decolorized when emancipated into the watery milieu. emancipation of these dyes in water gully is aesthetically undesirable and has a dangerous ecofriendly influences. It diminishes the solubility of gases, displays cumulative impact on the organisms and causes opposing impact on human lives [4].

Safranin-O and Methylene Blue (MB), a cationic dyes separated mostly in textile and pharmacologica linduistries.

Exposure to these effluents may be troublesome to aerobic systems, leather, and peptic tract infections when ingested [5]-[6]. It is, consequently, needful to decolorize waste water to the lowermost allowable concentricity with a view to the protection the water organizations as stated by ecological regulations.
Many handling procedures have been a proposition for dyes elimination from water [7]. Amongst these procedures adsorption is one of the most common at the present time [8]. This is because of its possible effectiveness, low consuming energy, high eclectic at the molecular level, easy actuation, and ability to isolate different chemical compounds [9]-[15].

The aim of this research was to determine the adsorption behaviour of two cationic dyes (Methylene Blue and Safranin-O) in aqueous solution on DML using the batch mode method.

\section{Experimental Part}

\section{Adsorbent and adsorbate preparation}

The Adsorbent was DML which purchase from the local market and then wash away with de-ionized water several times then dehydrated at $40^{\circ} \mathrm{C}$ for $24 \mathrm{hrs}$. These seeds were used as adsorbent surface for both dyes.

Safranin-O and Methylene Blue has been used in this paper as adsorbate Fig.(1) displays the chemical structure of these dyes. 


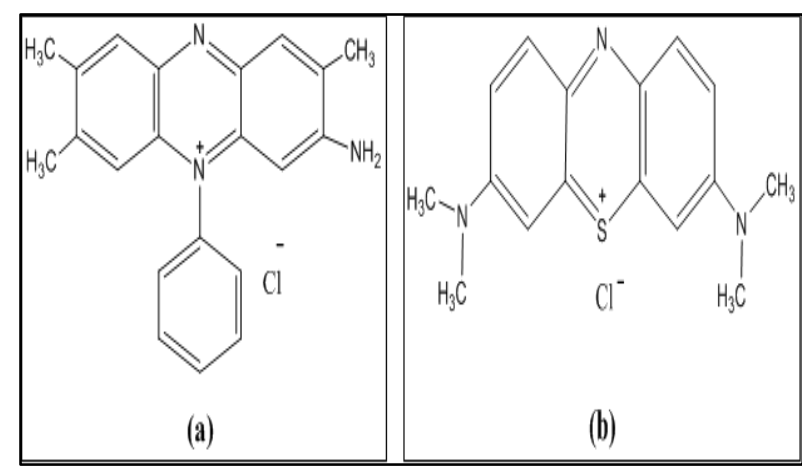

Fig.(1): The chemical structure of dyes: a. Safranin-O b. Methylene Blue.

Stock solutions of these cationic dyes were synthesized by resolving $20 \mathrm{mg}$ from dyes powder in $500 \mathrm{ml}$ distilled water to make a solution with concentration $40 \mathrm{mglL}$. subsequently, from these solutions a diluted solutions to diverse concentrations $(5,10,15$, $20,25,30, \ldots .$. , and 35$) \mathrm{mg} \backslash \mathrm{L}$ were synthesized [16].

\section{Batch Adsorption}

The adsorption experimentations were done by batch equilibrium technique. DML were placed in $250 \mathrm{ml}$ conical flask contains $100 \mathrm{ml}$ of the dye resolution. The flasks were placed on a rotary shaker (BS- 11; Korea) and shaken at $300 \mathrm{rpm}$ at $298 \mathrm{~K}$ and equilibrium time. The adsorbate resolution was centrifuged at $3000 \mathrm{rpm}$ for 15 minutes. The sample concentration was measured by UltravioletVisible spectro-photometer (Shimadzu UV1800) Germany at $\lambda_{\max }$ equal to $520 \mathrm{~nm}$ for safranine-O and $664 \mathrm{~nm}$ for methylene blue. The quantity of SF-O and MB adsorbed was examined from the equation below [17]:

$q_{e}=\frac{C_{0}-C_{e}}{m} \times V$

where: $\mathrm{Q}_{\mathrm{e}}=$ the quantity of dye that adsorbed per weight unit of DML $(\mathrm{mg} / \mathrm{g}) ; \mathrm{C}_{0}=$ the primary concentration of dyes $(\mathrm{mg} \backslash \mathrm{L}) ; \mathrm{C}_{\mathrm{e}}=$ the concentration of dyes in resolution at equilibrium time $(\mathrm{mg} \backslash \mathrm{L}) ; \mathrm{V}=$ the resolution volume $(\mathrm{L}) ; \mathrm{m}=$ the seeds quantity $(\mathrm{g})$.

Removal percentage or adsorption percentage was examined via equation (2):

$R \%=\frac{C_{o}-C_{e}}{C_{o}} \times 100$
Results and Discussions

Influence of several parameters on adsorption

\section{Influence of contact time}

The blend of DML $(0.1 \mathrm{~g})$ and dye resolution $(10 \mathrm{mg} / \mathrm{L})$ were agitated $298 \mathrm{~K}$ for diverse time $(15,30,45,60,75,90$, and 105) minutes and dyes concentration were specified at each time. The consequences obtained were displayed in Fig.(2a). Fig.(2a) displays that equilibrium was attained after shaking for 60 min and $90 \mathrm{~min}$ for $\mathrm{MB}$ and SF-O respectively, consequently these time were passable as the optimal time for adsorption of $\mathrm{MB}$ and SF-O on DML. A further rise in contact time did not display any rise in adsorption by reason of satiation in surface sites [18].

\section{Effect of adsorbent dose}

Primary concentration of dye $(10 \mathrm{mg} / \mathrm{L})$ was utilized in correlation with diverse amount of DML of $(0.025,0.05,0.1,0.15,0.25,0.3$ and $0.35 \mathrm{~g}$ ) and the other parameters were kept constant; contact time 60 and 90 min, agitation speed $300 \mathrm{rpm}$; temperature $298 \mathrm{~K}$. The consequences were clarified in Fig.(2b). The optimum absorbent amount was selected as $0.3 \mathrm{~g}$ for two dyes in which the removal efficacy R\% amounted a value of (87.73 and 82.03 with MB and SF-O respectively) this is because of the increment in availability of surface active sites resultant from the increased amount [19]. (a)

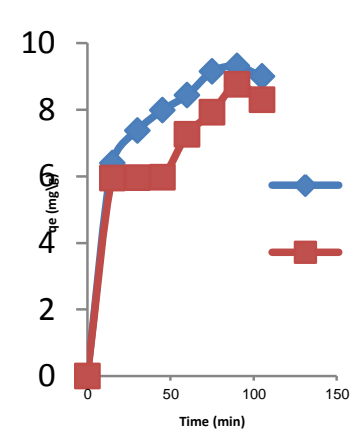

(b)

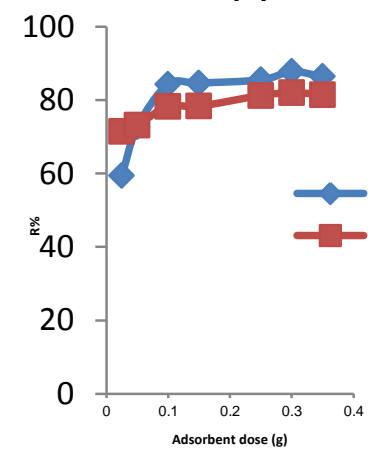

Fig.(2): (a) Influence of contact time on removal of $M B$ and $S F-O(10 \mathrm{mg} \backslash L$, concentration, $0.1 \mathrm{~g}$ adsorbent), (b) Effect of adsorbent amount on percentage adsorbed. Concentration $=10 \mathrm{mg} / \mathrm{L}$, Time $=(M B=60$ $\min , \mathrm{SF}-\mathrm{O}=90 \mathrm{~min}$.), Temperature $=298 \mathrm{~K}$. 


\section{Effect of adsorbate concentration and temperature}

The influence of primary concentration of dyes with values of $5,10,15,20,25,30,35$, and $40 \mathrm{mg} / \mathrm{L}$ ) was carried out to monitor the absorption efficacy at a fixed adsorbent amount $(0.3 \mathrm{~g})$ and diverse temperatures (298, 308,318 and $328 \mathrm{~K}$ ). The contact time was kept $60 \mathrm{~min}$ and $90 \mathrm{~min}$ for $\mathrm{MB}$ and FS-O respectively. From consequences depict that dye uptake increases with increase in primary concentration from 5 to $40 \mathrm{mg} / \mathrm{L}$. The increment in sorption capability may be due to the increase of dye concentration which caused in the higher concentration gradient of the dye, thus leading to higher sorption capability [20]. also, noted that the rate of uptake of dye was lowered with the rise in temperature, this is pointing to that the process is exothermic in nature. This lowers in adsorption efficacy withrising in temperature may be because of the weakening of adsorptive forces between the active sites of the adsorbent and adsorbate [21]. The consequences also point to that the adsorption efficacy for MB was more than SF$\mathrm{O}$ [22].

\section{Thermodynamic Calculations}

To understand better the effect of temperature on the adsorption, it is required to detect the thermodynamic parameters of adsorption, enthalpy change $\left(\Delta \mathrm{H}^{\circ}\right)$, entropy change $\left(\Delta \mathrm{S}^{\circ}\right)$ and Gibbs free energy change
$\left(\Delta \mathrm{G}^{\mathrm{o}}\right) . \quad \Delta \mathrm{H}^{\mathrm{o}}$ has been computed for each adsorption procedures as stated by Van't Hoff's equation (equation 3) by graphing logarithmic of the adsorption equilibrium constant $\left(\mathrm{K}_{\mathrm{eq}}\right)$ as $\left(\ln \mathrm{q}_{\mathrm{e}} / \mathrm{C}_{\mathrm{e}}\right)$ vs. (1/T) [23].

Table (1) and Fig.(3).

$\ln K e q=\frac{-\Delta H^{\circ}}{R T}+\frac{\Delta S^{\circ}}{R}$

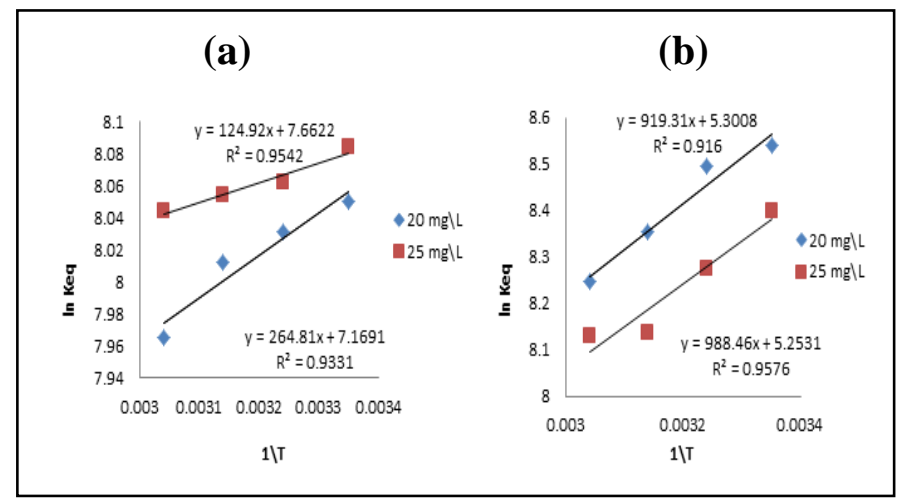

Fig.(3): Van't Hoff equation of adsorption of two dyes onto DML for primary dye concentration of $(20 \& 25) \mathrm{mg} \backslash \mathrm{L}$,

$$
\text { a. } \mathrm{MB} \text { b. SF-O. }
$$

The Gibbs free energy of adsorption $\left(\Delta \mathrm{G}^{\mathrm{o}}\right)$ numerated from equation 4 [24]:

$\Delta \mathrm{G}^{\circ}=-\mathrm{RT} \ln \mathrm{K}$

As qe/ $\mathrm{Ce}=\mathrm{K}_{\mathrm{eq}}$ and $\mathrm{Q}_{\mathrm{e}}$ should be in $\mathrm{mg} / \mathrm{kg}$. Table (2) clarifies the values of thermodynamic functions of the adsorption of the two dyes on the surface of the DML.

Table (1)

Values of In $K_{e q}$ and thermodynamic parameters for the $M B$ and $S F-O$ adsorption $\left(C_{0}=20\right.$ and $25 \mathrm{mg}(\mathrm{L})$ at diverse temperatures.

\begin{tabular}{|c|c|c|c|c|c|c|c|c|}
\hline $\begin{array}{l}\frac{3}{3} \\
\frac{3}{3} \\
\frac{3}{2}\end{array}$ & Co $(\mathrm{mg})$ & $T(\mathcal{K})$ & $\begin{array}{l}C_{e} \\
(m g / L)\end{array}$ & $g_{e}(\mathrm{mg} / \mathrm{g})$ & ba $K_{\text {eq. }}$ & $\begin{array}{l}\Delta G^{-} \\
\text {aJimel }\end{array}$ & $\begin{array}{l}\Delta S^{-} \\
\left(J / \text { Kmol }^{\prime}\right.\end{array}$ & $\begin{array}{l}\Delta H^{\circ} \\
\text { AJ mal }\end{array}$ \\
\hline \multirow{2}{*}{$\mathrm{MB}$} & 20 & $\begin{array}{l}298 \\
308 \\
318 \\
328\end{array}$ & $\begin{array}{l}1.394 \\
1.567 \\
1.774 \\
1.786\end{array}$ & $\begin{array}{l}6.202 \\
6.144 \\
6.075 \\
6.071\end{array}$ & $\begin{array}{l}8.4 \\
8.274 \\
8.138 \\
8.131\end{array}$ & $\begin{array}{l}-19.94 \\
-20.56 \\
-21.18 \\
-21.72\end{array}$ & 59.603 & -2.201 \\
\hline & 25 & $\begin{array}{l}298 \\
308 \\
318 \\
328\end{array}$ & $\begin{array}{l}1.528 \\
1.595 \\
1.819 \\
2.010\end{array}$ & $\begin{array}{l}7.801 \\
7.801 \\
7.727 \\
7.663\end{array}$ & $\begin{array}{l}8.54 \\
8.495 \\
8.354 \\
8.246\end{array}$ & $\begin{array}{l}-20.02 \\
-20.64 \\
-21.29 \\
-21.93\end{array}$ & 63.703 & -1.038 \\
\hline \multirow[t]{2}{*}{ SF-O } & 20 & $\begin{array}{l}298 \\
308 \\
318 \\
328\end{array}$ & $\begin{array}{l}1.921 \\
1.955 \\
1.989 \\
2.075\end{array}$ & $\begin{array}{l}6.026 \\
6.015 \\
6.003 \\
5.975\end{array}$ & $\begin{array}{l}8.05 \\
8.031 \\
8.012 \\
7.965\end{array}$ & $\begin{array}{l}-20.81 \\
-21.18 \\
-21.51 \\
-22.17\end{array}$ & 44.070 & -7.643 \\
\hline & 25 & $\begin{array}{l}298 \\
308 \\
318 \\
328\end{array}$ & $\begin{array}{l}2.404 \\
2.376 \\
2.393 \\
2.416\end{array}$ & $\begin{array}{l}7.556 \\
7.541 \\
7.535 \\
7.528\end{array}$ & $\begin{array}{l}8.084 \\
8.062 \\
8.054 \\
8.044\end{array}$ & $\begin{array}{l}-21.15 \\
-21.75 \\
-22.08 \\
-22.48\end{array}$ & 43.674 & -8.218 \\
\hline
\end{tabular}


From the outcomes displayed in the Table (1), we deduced that the values of the alteration in Gibbs free energy $\left(\Delta \mathrm{G}^{\circ}\right)$ were negative at all tested temperatures $(25-55)^{\circ} \mathrm{C}$, verifying that the adsorption of $\mathrm{MB}$ and $\mathrm{SF}-\mathrm{O}$ dyes onto DML were spontaneous and thermodynamically favorable. As temperature growing from 25 to $55^{\circ} \mathrm{C}, \Delta \mathrm{G}^{\circ}$ downgraded (increasingly negative), propounding that adsorption was spontaneous at elevated temperatures. The negative $\Delta \mathrm{H}^{\circ}$ values point to that the adsorption of two dyes onto DML was an exothermic process [25], which is reinforced by the downgraded in adsorption of the dye as temperature growing. Furthermore, the positive $\Delta \mathrm{S}^{\circ}$ point out that the degrees of freedom augmented at the solid-liquid interface thru adsorption of the two dyes onto DML. Physi-sorption and chemisorption can be categorized, to the surest range, by the quantity of enthalpy change. So, the values of $\Delta \mathrm{H}^{\circ}$ propound that adsorption of $\mathrm{MB}$ and $\mathrm{SF}$ $\mathrm{O}$ onto DML were driven by a physisorption.

\section{Adsorption Isotherms}

Adsorption isotherms are essential for the prescribing of just how adsorbates will combine with an adsorbent and are critical in optimum the usage of adsorbent [12]. Adsorption isotherms of $\mathrm{MB}$ and $\mathrm{SF}-\mathrm{O}$ on DML at diverse temperature $(25,35,45$, and $55)^{\circ} \mathrm{C}$ were clarified in Figs.(4-5). The study elucidated that the adsorption isotherm of both MB and SF-O dyes on DML was nonlinear and typical S-shape curves which refer to the perpendicular or planar orientation of adsorbate, and is monofunctional [13].

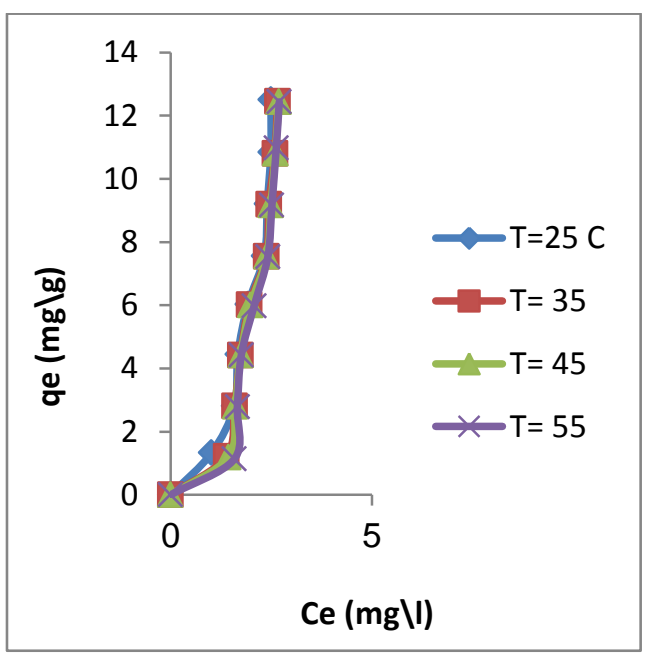

Fig.(4): Adsorption isotherm of MB on DML at different temperatures.

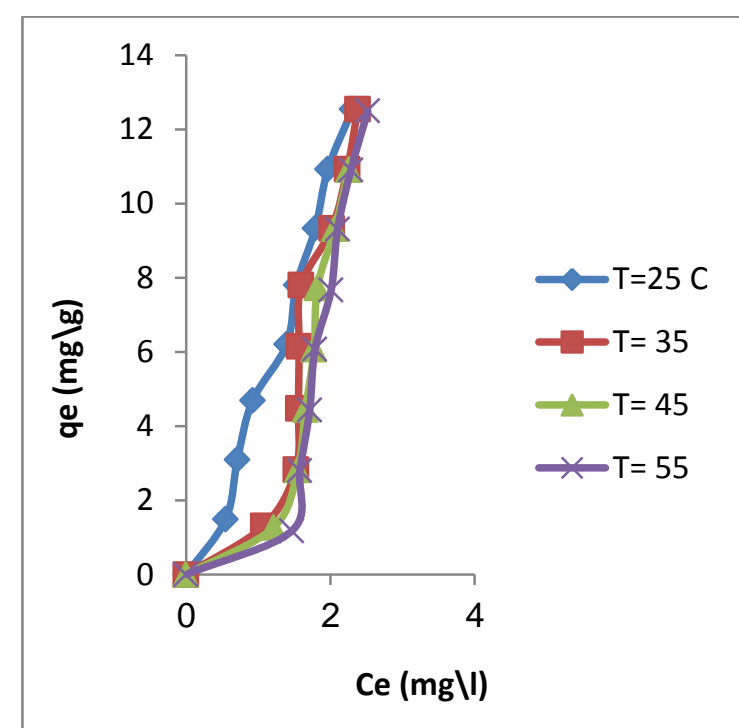

Fig. (5): Adsorption isotherm of SF-O on DML at different temperatures.

Numerous mathematical paradigm can be utilized to depict empirucal statements of adsorption isotherms. Three renowned isotherm equations, the Langmuir, Freundlich, and Dubinin-Radushkevich were usage for further interpretation of the obtained adsorption statements.

\section{Langmuir Isotherm}

The Langmuir model prescribes the monolayer adsorption. It presumes unified energy of adsorption, a monadic (homogenous) layer of adsorbed solute at a fixed temperature [14]. The linear configuration of Langmuir equation is:

$$
\frac{1}{q_{e}}=\frac{1}{Q^{\circ} K_{L} C_{e}}+\frac{1}{Q^{\circ}}
$$

Where: $\mathrm{C}_{\mathrm{e}}=$ the dye concentration at equilibrium; $\mathrm{q}_{\mathrm{e}}=$ the quantity of dye adsorbed at equilibrium; $\mathrm{Q}^{\circ}(\mathrm{mg} / \mathrm{g})$ and $\mathrm{K}_{\mathrm{L}}(\mathrm{L} / \mathrm{mg})=$ Langmuir constants. $\mathrm{Q}^{\circ}$ is the monolayer adsorption capability and $\mathrm{K}_{\mathrm{L}}$ is constant correlated to the free energy of adsorption. $\mathrm{Q}^{\circ}$ and $\mathrm{K}_{\mathrm{L}}$ were delineated from the slope and intercept respectively when graphing $1 / \mathrm{q}_{\mathrm{e}}$ vs. $1 / \mathrm{C}_{\mathrm{e}}$ (see Figs. 6-7 and Table 2).

\section{Freundlich Isotherm}

Freundlich isotherm linear equation clarify below [15]:

$$
\log q_{e}=\log K_{f}+\frac{1}{n} \log C_{e}
$$

$\mathrm{K}_{\mathrm{f}}$, and $\mathrm{n}$ is the Freundlich constants. 
The Freundlich model is an empirical equation that is quite beneficial in depicting the dispersal of solute between solid and aqueous phases at a point of satiety. Values of $\mathrm{K}_{\mathrm{f}}$ and $\mathrm{n}$ respectively are accessed from intercept and slope of the linear graphing of $\log \mathrm{q}_{\mathrm{e}}$ vs. $\log \mathrm{C}_{\mathrm{e}}$, (See Figures 8- 9 and Table 2).

\section{Dubinin-Radushkevich (D-R) Isotherm}

$\mathrm{D}-\mathrm{R}$ isotherm is else isotherm equation that utilized in this research. For solid-liquid interface the linear shape of DubininRadushkevich (D-R) isotherm (equation 7) clarified below [26]:

$$
\begin{aligned}
& \ln q_{e}=\ln q_{m}-\beta \varepsilon^{2} \\
& \varepsilon=R T \ln \left(1+\frac{1}{C_{e}}\right)
\end{aligned}
$$

$\mathrm{q}_{\mathrm{m}}=$ the adsorption capability of the adsorbent ( $\left.\mathrm{mg} \mathrm{g}^{-1}\right), \beta=$ a constant correlated to the adsorption energy $\left(\mathrm{mol}^{2} \mathrm{~kJ}^{-2}\right), \mathrm{R}=$ the gas constant $\left(\mathrm{J} \mathrm{K}^{-1} \cdot \mathrm{Mol}^{-1}\right)$, and $\mathrm{T}=$ the temperature (K). The D-R model is essential for foretelling the nature of adsorption process through the delineating of the mean adsorption energy (E) by utilizing equation [27]: $E=\frac{1}{\sqrt{2 \beta}}$ (See Figs.10, 11\&Table 2).

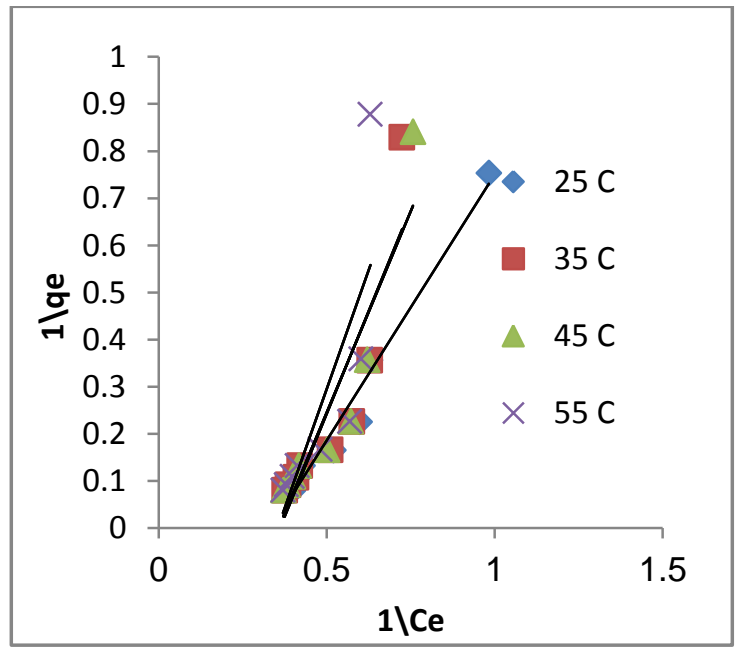

Fig. (6): Graphing of Langmuir models for adsorption of MB on DML at diverse temperatures.

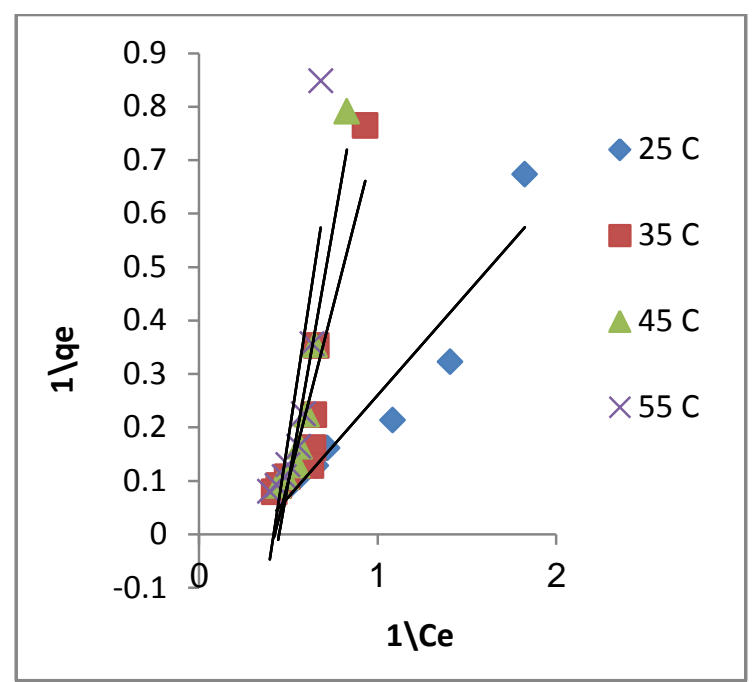

Fig.(7): Graphing of Langmuir models for adsorption of $\mathrm{SF}-\mathrm{O}$ on $\mathrm{DML}$ at diverse temperatures.

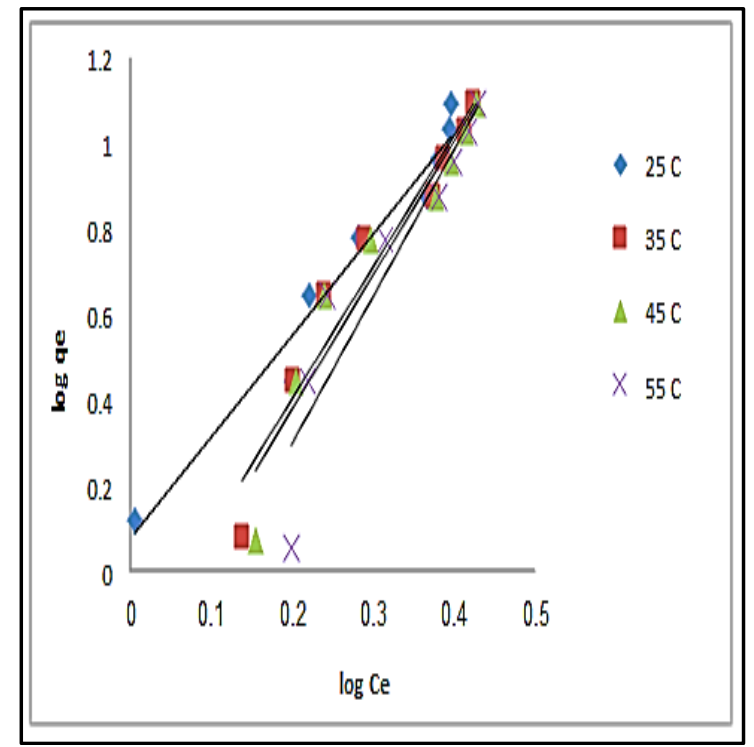

Fig.(8): Graphing of Freundlich models for adsorption of MB on DML at diverse temperatures.

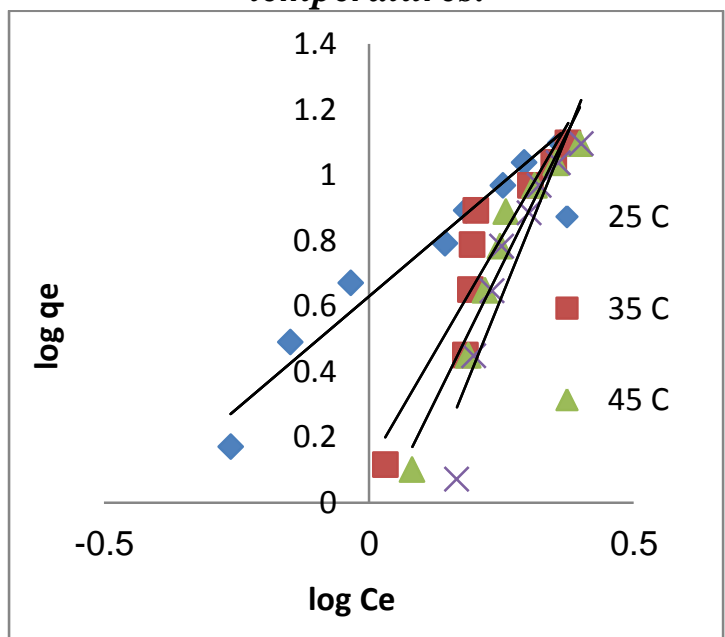

Fig.(9): Graphing of Freundlich models for adsorption of $\mathrm{SF}-\mathrm{O}$ on $\mathrm{DML}$ at diverse temperatures. 


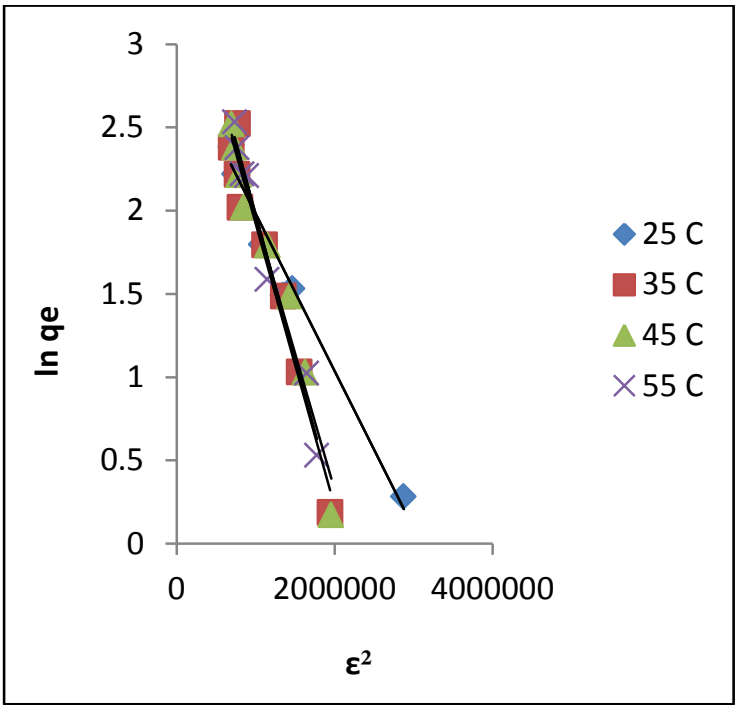

Fig.(10): Graphing of Dubinin-Radushkevich models for adsorption of MB on DML at diverse temperatures.

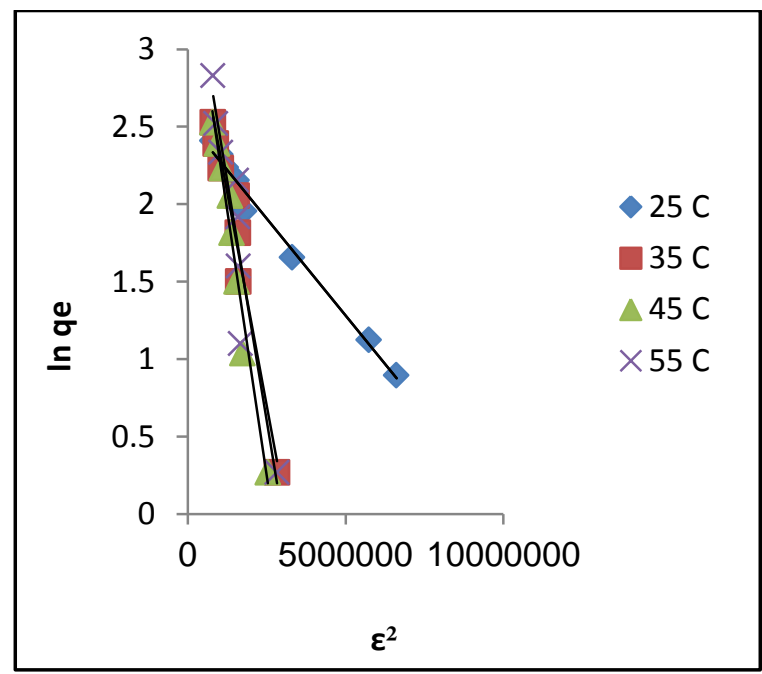

Fig.(11): Graphing of Dubinin-Radushkevich models for adsorption of SF-O on DML at diverse temperatures.
Table (2)

Parameters values of the isotherms for the $M B$ and $S F-O$ dyes adsorption onto DML.

\begin{tabular}{|c|c|c|c|c|c|c|c|c|c|c|}
\hline \multicolumn{2}{|c|}{ Model } & \multicolumn{3}{|c|}{ Langmuir } & \multicolumn{3}{|c|}{ Erendliech } & \multicolumn{3}{|c|}{ Dubinin-Radushksvich } \\
\hline Adsorbate & $T(K)$ & $\begin{array}{c}Q^{2} \\
(\mathrm{mg} \mathrm{g})\end{array}$ & $\begin{array}{c}K_{L} \\
(L / g)\end{array}$ & $\overline{R^{2}}$ & $n$ & $K_{F}$ & $R^{2}$ & $\begin{array}{c}g_{n} \\
(\mathrm{mg} g)\end{array}$ & $\begin{array}{c}\bar{E} \\
(\mathrm{k} / \mathrm{Nol})\end{array}$ & $R^{2}$ \\
\hline \multirow{4}{*}{$M B$} & 298 & -2639 & -0.335 & 0.9738 & 0.419 & 1187 & 0.965 & 18701 & 0745 & 0.9784 \\
\hline & 308 & -1.583 & -0.361 & 0.8003 & 0.323 & 0.610 & 0.939 & 31.290 & 0.5 & 0.9617 \\
\hline & 318 & -1.642 & -0.355 & 0.8505 & 0.318 & 0.564 & 0.925 & 36.313 & 0.5 & 0.9789 \\
\hline & 328 & -1.396 & -0.354 & 0.6433 & 0.292 & 0.413 & 0.867 & 41.545 & 0.5 & 0.9789 \\
\hline \multirow{4}{*}{ SF-0 } & 298 & -8.319 & -0.315 & 0.9044 & 0.727 & 4.255 & 0.9646 & 12.584 & 1.291 & 0.9784 \\
\hline & 308 & -1.803 & -0.424 & 0.8384 & 0.359 & 1.298 & 0.863 & 31.380 & 0.707 & 0.9489 \\
\hline & 318 & -1.174 & -0.448 & 0.9218 & 0.304 & 0.797 & 0.9391 & 39.650 & 0.707 & 0.9718 \\
\hline & 328 & -1.1046 & -0.417 & 0.6853 & 0.250 & 0.425 & 0.8756 & 40.100 & 0.707 & 0.9789 \\
\hline
\end{tabular}

It can be obvious from Table (2) that the correlation coefficient values $\mathrm{R} 2$ that the Freundlich isotherm (Fig.10,11) model convenient the data better than the Langmuir model (Fig.8,9). The values obtained for the Freundlich constant $\mathrm{n}$ less than 10 is an adverting that the two dyes have a high affinity for DML molecules. The magnitude of $\mathrm{K}_{\mathrm{f}}$ revealed the lower uptake of two dyes at supreme temperature allusion to exothermic nature of adsorption process.

Similarly, the values of $\mathrm{R}^{2}$ for $\mathrm{MB}$ and SF$\mathrm{O}$ elucidated that the empirical data obtained conveniently to the D-R isotherm (Fig. 12, 13) and Table (2). The removal of $\mathrm{MB}$ and SF-O on DML is a physical process inasmuch the valuable of free energy (E) accessed were found to be $<8 \mathrm{~kJ} \mathrm{~mol}^{-1}$ [28].

\section{Conclusions}

The Practical survey of adsorption MB and SF-O on DML point to the following:-

- The DML were good adsorbents for the remedying of textile wastewater involving $\mathrm{MB}$ and SF-O.

- The adsorption has better comply with the Freundlich adsorption isotherm than Langmuir equation.

The adsorption is physisorption, this is revealed by the values of $\Delta \mathrm{H}^{\mathrm{o}}$ and $\mathrm{E}$ extractive from Vants Hoff and DubininRadushkovich equations. 
- Thermodynamic data outcomes extractive has pointed to that the adsorption processes are spontaneous and exothermic.

\section{References}

[1] Lean T., Mohd S., Noordin J., and Kassim M., Acidic and Basic Dyes Removal by Adsorption on Chemically Treated Mangrove Barks. International Journal of Applied Science and Technology,2,3, 2012.

[2] Akinola K., and Umar M., Adsorption of Crystal Violet onto Adsorbents Derived from Agricultural Wastes: Kinetic and Equilibrium Studies. J. Appl. Sci. Environ. Manage, 19, 279- 288, 2015.

[3] Muhammad B., Ibrahim A., and Haruna I., Optimization of Crystal Violett dye Removal from Aqueous Solution using Agro Wastes. Chemsearch Journal, 3, 28 33, 2012.

[4] Guaratini C., and Zanoni B., Textile dyes. Quim. Nova., 23, 71-78, 2000.

[5] Bayazit S., Investigation of Safranin O adsorption on superparamagnetic iron oxide nanoparticles (SPION) and multi-wall carbon nanotube/SPION composites. Desalin. Water Treat, 1-10, 2013.

[6] Zohre S., Ataallah G., and Mehdi A., Experimental study of methylene blue adsorption from aqueous solutions onto carbon nano tubes. International Journal of Water Resources and Environmental Engineering, 2, 016-028, 2010.

[7] Kurbus T., Slokar M., and Le Marechal M., The study of the effects of the variables on $\mathrm{H}_{2} \mathrm{O}_{2} / \mathrm{UV}$ decoloration of vynylsulfone dye: part II. Dyes Pigments, 54, 67-78, 2002.

[8] Ghislain A., Andrada M., Jean M., Chrisdel N., and Richard K., Optimitization of Crystal Violet Adsorption Performances on to $\mathrm{H}_{3} \mathrm{PO}_{4}$-Modified Mango Seeds Kernel using a Box-Behnken Experimental Design. International Journal of Chem Tech Research, 8, 502-510, 2015.

[9] Shanmugaprakash M., Sivakumar V., Prasana J., and Nandusha K., Biosorption of $\mathrm{Cr}(\mathrm{VI})$ and $\mathrm{Zn}(\mathrm{II})$ ions from aqueous solution onto the solid biodiesel waste residue: mechanistic, kinetic and thermodynamic studies. Environ. Sci. Pollut. Res., 21, 593-608, 2014.

[10] Debora P., Carla D., Francielle Z., Danielle M., and Clo' vis R., Adsorption of rhodamine $\mathrm{B}$ and methylene blue dyes using waste of seeds of Aleurites Moluccana, a low cost adsorbent. Alexandria Engineering Journal, 5, 17131723, 2016.

[11] Sammer K., and Enaas A., Adsorption of congo red, rhodamin $\mathrm{B}$ and disperse blue dyes from aqueous solutions onto raw flint clay. Journal of Baghdad for science, 4, 680-688, 2012.

[12] Theivarasu C., Mylsamy S., and Sivakumar N., Adsorptive Removal of Crystal Violet Dye Using Agricultural Waste Cocoa (theobroma cacao) Shell. Research Journal of Chemical Sciences, 7, 38-45, 2011.

[13] Ibrahim Q., Ali I., Kareem S., Removal of cetyldimethylbenzylammonium chloride surfactant from aqueous solution by adsorption onto mesoporous silica. International journal of science and research, 5, 6-391, 2016.

[14] Bharathi K., and Ramesh S., Removal of dyes using agricultural waste as low-cost adsorbents: A review. Appl. Water Sci., 3, $773-790,2013$.

[15] Taha E., Equilibrum Isotherms and Kinetic Studies of Removal of Methylene Blue Dye by Adsorption onto Miswak Leaves as Natural Adsorbent. Journal of Environmental Protection, 2, 817-827, 2011.

[16] Enenebeaku C., Okorocha N., Enenebeaku U., Anukam B., Onyeocha V., Ogukwe C., and Oguzie E., Adsorption of Congo Red Dye from Aqueous Solution Using Agricultural Waste. IOSR Journal of Applied Chemistry, 9, 39-51, 2016.

[17] Fatima K., Laila L., Abdelkebir K., Tarik A., M'hamed E., Samia Y., and Mohammed T., Optimization of Adsorption Performance of an Industrial Dye on Waste Mint by the Design of Experiments Method-Composite Centered Plan. International Journal of Science and Research (IJSR)., 4, 1171-1174, 2015.

[18] Ainane T., Khammour F., Belghazi O., Kabbaj M., Yousfi S., Talbi M., and Elkouali M., Study and modelling of kinetics biosorption of methylene blue on biomass material from waste mint BTAIJ., 11, 281-285, 2015. 
[19] AL-Rufaie E., and Hassan S., Adsorption study of methylene blue dye on weld seeds in aqueous solutions. International Journal of Emerging Trends \& Technology in Computer Science (IJETTCS), 5, 1-6, 2016.

[20] Vajapara S., Patel S., and Bhasin C., Efficient Adsorption and Photocatalytic Degradation of Malachite Green Dye Using Bentonite Natural Adsorbent. Int. J. Nano. Chem., 3, 33-37, 2017.

[21] El-Bindary A., El-Sonbati A., Shoair A., Mohamed A., Adsorptive removal of hazardous azorhodanine dye from an aqueous solution using rice straw fly ash. J. Mater. Environ. Sci., 6, 1723-1732, 2015.

[22] Singh H., and Roohi S., Removal of basic dyes from aqueous solutions using mustard waste ash and buffalo dung ash, International journal of environmental science, 3, 1711-1725, 2013.

[23] Nandi K., Goswami A., and Purkait K., adsorption characteristics of brilliant green dye on kaolin. Journal of Hazardous Materials, 161, 387-95, 2009.

[24] Al Othman A., Hashem A., and Habila M., Kinetic, equilibrium and thermodynamic studies of cadmium (II) adsorption by modified agricultural wastes. Molecules, 16, 0443-10456, 2011.

[25] Youssef M., Al-Awadhi M., and Akl A., Solid Phase Extraction and Spectrophotometric Determination of Methylene Blue in Environmental Samples using Bentonite and Acid Activated Bentonite from Egypt. Analytical \& bioanalytical techniques, 5, 2-8, 2014.

[26] Sameer K., Inaam A., and Moayyed J., Kinetic and Thermodynamic Study of Triton X-100 Removal from Aqueous Solution of Functionalized Mesoporous Silica. international journal of science; basic and applied research, 21, 293-308, 2015.

[27] Cleiton A., Nunes E., and Mário C., Estimation of Surface Area And Pore Volume of Activated Carbons by Methylene Blue and Iodine Numbers. Quim. Nova, 34, 472-476, 2011.

[28] Chinenye I., Pius O., Okechukwu O., and Ikenna N., Adsorptive Treatment of Textile Wastewater Using Activated Carbon Produced from Mucuna pruriens Seed
Shells. World Journal of Engineering and Technology, 4, 21-37, 2016. 